\title{
Identification and Pathogenicity of Fungal Pathogens Associated with Stem-End Rot of Avocado in California
}

M. Twizeyimana, H. Förster, V. McDonald, D. H. Wang, J. E. Adaskaveg, and A. Eskalen, Department of Plant Pathology and Microbiology, University of California, Riverside, CA 92521

\begin{abstract}
Twizeyimana, M., Förster, H., McDonald, V., Wang, D. H., Adaskaveg, J. E., and Eskalen, A. 2013. Identification and pathogenicity of fungal pathogens associated with stem-end rot of avocado in California. Plant Dis. 97:1580-1584.

Stem-end rot of harvested avocado fruit commonly occurs wherever the crop is cultivated. Multiple fungal species have been described as causal agents. To determine the causal pathogens of stem-end rot in California, fungal isolations were conducted from symptomatic fruit, and fungi were identified by morphological and molecular techniques. In 2010 and 2011, a total of 177 isolates were recovered from 290 avocado fruit collected from seven orchards in one of the major avocado growing areas in Southern California. The majority of isolates was identified as Neofusicoccum luteum (65\%), with the remainder either as Colletotrichum gloeosporioides (33\%) or Phomopsis sp. $(2 \%)$. In a pathogenicity test, $N$. luteum caused significantly $(P<0.05)$

more severe stem-end rot than either $C$. gloeosporioides or Phomopsis sp. No significant $(P>0.05)$ differences in stem-end rot severity were observed between inoculations with $N$. luteum isolated from fruit stemend rot and $N$. luteum or $N$. parvum isolated from branch cankers. This confirms that stem-end rot of avocado can be initiated by fungi causing branch cankers. Although low humidity and rainfall during much of the growing and harvest seasons in California are considered unfavorable conditions for the development of avocado stem-end rot, the identification of the causal pathogens is of value when decays have to be managed during outbreaks, and it stresses the importance of managing branch cankers.
\end{abstract}

Stem-end rot of avocado (Persea americana Mill.) has been reported from all major production areas worldwide $(12,17)$. Crop losses may be severe when harvest occurs during rainy periods (9). The first visible symptom of stem-end rot is a shriveling around the stem base that is followed by decay, fruit discoloration, and softening. The decay ultimately consumes the entire fruit. Internally, the decayed flesh is brown and the vascular bundles in advance of the decay may darken. Despite the long period of exposure to potential pathogens, fruit rarely display symptoms before harvest. Thus, in commercial avocado production, stem-end rot mostly occurs during transit, in the packinghouse, and during or after marketing.

Various fungi cause stem-end rot of avocado. They include species in the Botryosphaeriaceae such as Botryosphaeria lutea A.J.L. Phillips (anamorph Neofusicoccum luteum (Pennycook \& Samuels) Crous, Slippers \& A.J.L. Phillips), Botryosphaeria dothidea (Moug. ex Fr.) Ces. \& De Not. (anamorph Fusicoccum aesculi Corda), B. parva Pennycook \& Samuels (anamorph Neofusicoccum parvum (Pennycook \& Samuels) Crous, Slippers \& A.J.L. Phillips), B. ribis Grossenb. \& Duggar (anamorph Neofusicoccum ribis (Slippers, Crous \& M.J. Wingf.) Crous, Slippers \& A.J.L. Phillips), and B. rhodina (Berk. \& M.A. Curtis) Arx (anamorph Lasiodiplodia theobromae (Pat.) Griffon \& Maubl.). Other species reported include Glomerella cingulata (Stoneman) Spauld. \& H. Schrenk (anamorph Colletotrichum gloeosporioides (Penz.) Penz. $\&$ Sacc.), Glomerella acutata Guerber \& J.C. Correll (anamorph $C$. acutatum J.H. Simmonds), Nectria pseudotrichia (Schwein.) Berk. \& M.A. Curtis, and species of Albonectria, Alternaria, Gibberella, Pestalotiopsis, Phomopsis, and Rhizopus (12,13,17,20-22,26). Colletotrichum spp. can also cause fruit anthracnose (24).

Botryosphaeriaceae spp., which are generally recovered in greater numbers from stem-end rot of avocado fruit than other fungi and are often associated with severe rots (26), vary by

Corresponding author: A. Eskalen, E-mail: akif.eskalen@ucr.edu

Accepted for publication 11 June 2013.

http://dx.doi.org/10.1094/PDIS-03-13-0230-RE

(c) 2013 The American Phytopathological Society geographical region. For instance, the main cause of stem-end rot in Israel was reported to be Lasiodiplodia theobromae; in Australia and New Zealand, Neofusicoccum luteum and N. ribis; and in South Africa, N. luteum and Nectria pseudotrichia (17). In the United States, B. dothidea was reported as the causal pathogen (17), but extensive surveys were never done. Furthermore, in elucidating the etiology of stem-end rots, recent taxonomic revisions of the Botryosphaeriaceae based on molecular data (2) should be considered. Combined morphological characteristics and sequence data from multiple genes or gene regions have recently been used to distinguish and identify species within the Botryosphaeriaceae $(2,23)$.

Stem-end rot pathogens are present in living and dead branches, twigs, leaves, and in living pedicels $(6,13)$ or sometimes in the soil (17). Inoculum is produced at high humidity and disseminated by rain splash, wind, or by shaking of branches when fruit are harvested (13). Although some infections originate from endophytic colonization that remains latent until after harvest (17), most stemend infections probably occur at harvest when spores contaminating the stem surface are distributed by cutting tools $(8,15)$. After infection, the fruit is gradually colonized. In contrast, pathogens that cause fruit body rots invade through the intact or injured fruit skin (26). Some pathogens, such as Colletotrichum and Botryosphaeria species, are also known to cause latent infections that become activated when physiological and biochemical changes that are associated with a reduction in the concentration of fungal inhibitors are initiated in the harvested fruit $(15,21)$.

Stem-end rots are generally a relatively minor problem of avocados in California due to low relative humidity and rainfall during much of the growing season and harvest time (10). Early-season fruit harvested in spring, however, may develop a high incidence of stem-end rot due to a high level of fruit surface contamination by spores of the pathogens. Spores of fungi in the Botryosphaeriaceae and Diaporthaceae that may serve as inoculum for stem-end rot were detected in a spore trap study in eight avocado groves in the major avocado producing areas in Southern California during the rainy season, which extends from November to April (7).

Objectives of this study were to identify fungi associated with avocado stem-end rot in a major avocado growing area of California, evaluate their pathogenicity on avocado fruit, and compare 
their pathogenicity to that of several related pathogens previously isolated from branch cankers (16).

\section{Materials and Methods}

Fungal isolation. In 2010 and 2011, avocado fruit 'Hass' were harvested by clipping from seven orchards in the Fallbrook area, San Diego County, a major avocado growing region of California. Approximately 290 fruit were randomly harvested and transported to the laboratory and incubated for 2 to 3 weeks at $24^{\circ} \mathrm{C}$ to allow stem-end rot to develop. Small pieces of symptomatic flesh from the margins of decay were placed onto potato dextrose agar (PDA; Difco Laboratories, Detroit, MI) acidified with $10 \mathrm{ml}$ of $25 \%$ (vol/vol) lactic acid per liter in petri dishes and incubated at $24^{\circ} \mathrm{C}$ for 3 to 5 days. Pure cultures were obtained by transferring mycelial tips from the colony margin onto fresh acidified PDA. Additional isolates recovered from avocado branch cankers between 2008 and 2009 were available from a previous study (16).

Fungal identification. Isolates were grown on PDA amended with $0.01 \%$ tetracycline hydrochloride (Sigma-Aldrich, St. Louis, MO) (PDA-tet) to morphologically distinguish species in the genera of Botryosphaeria, Colletotrichum, and Phomopsis. Cultures belonging to the Botryosphaeriaceae were transferred to $2 \%$ water agar amended with autoclaved pine needles or avocado wood chips to induce pycnidia production (16). Petri dishes were incubated at $25^{\circ} \mathrm{C}$ with a 12 -h photoperiod for up to 4 weeks. Morphological characteristics were evaluated as previously described and compared to reference isolates (16).

For molecular characterization, DNA was extracted from representative isolates following the method described by Cenis (1). Primers ITS4 and ITS5 were used to amplify the internal transcribed spacer ITS1 and ITS2, including the 5.8S region of rDNA (25). A partial sequence of the $\beta$-tubulin gene was amplified using primers Bt2a and Bt2b (11). A 25- $\mu$ l PCR reaction mixture con- tained $0.25 \mu \mathrm{M}$ of each primer, $12.5 \mu \mathrm{l}$ of Promega master mix (Promega, Madison, WI), and $2 \mu \mathrm{l}$ of DNA template. PCR reactions were done in a thermal cycler (Bio-Rad Laboratories Inc., Hercules, CA) using the following programs: (i) initial denaturation at $95^{\circ} \mathrm{C}$ for $2 \mathrm{~min}$; followed by 35 cycles of denaturation at $95^{\circ} \mathrm{C}$ for $30 \mathrm{~s}$, annealing at $58^{\circ} \mathrm{C}$ for $30 \mathrm{~s}$, and extension at $72^{\circ} \mathrm{C}$ for $60 \mathrm{~s}$; and a final extension at $72^{\circ} \mathrm{C}$ for $5 \mathrm{~min}$ for the ITS region, and (ii) initial denaturation at $94^{\circ} \mathrm{C}$ for $2 \mathrm{~min}$; followed by $40 \mathrm{cy}-$ cles of denaturation at $94^{\circ} \mathrm{C}$ for $30 \mathrm{~s}$, annealing at $51^{\circ} \mathrm{C}$ for $45 \mathrm{~s}$, and extension at $72^{\circ} \mathrm{C}$ for $90 \mathrm{~s}$; and a final extension at $72^{\circ} \mathrm{C}$ for 5 min for the $\beta$-tubulin gene.

PCR products were purified using the QIAquick PCR purification kit (Qiagen Inc., Valencia, CA) and sequenced in both directions at the Institute for Integrative Genome Biology, University of California, Riverside. Sequences were edited using the program Sequencher 4.6 (Gene Codes Corp., Ann Arbor, MI) and aligned using Clustal X 2.1-Mac OSX (Conway Institute, UCD, Dublin, Ireland). Sequences of representative isolates of each morphological group were used to search for similar sequences in GenBank using the BLAST (version 2.0, National Center for Biotechnology Information, United States National Institutes of Health, Bethesda, MD).

Phylogenetic analysis and genetic variation. Sequences of representative isolates in the genus Neofusicoccum from stem-end rot and branch cankers, as well as several sequences from GenBank (Table 1), were used in a phylogenetic analysis. A Guignardia philoprina (CBS447.68) sequence from GenBank was chosen as an outgroup. The phylogenetic analysis was performed using MEGA 5.0. Maximum parsimony analysis was done using the heuristic search with a close-neighbor interchange (CNI) branch swapping option. Alignment gaps were treated as missing data. Support for each branch in the inferred trees was evaluated by 1,000 bootstrap replications. Prior to the heuristic search of the

Table 1. Isolates of species in the genus Neofusicoccum used in the phylogenetic analysis

\begin{tabular}{|c|c|c|c|c|c|}
\hline \multirow[b]{2}{*}{ Isolate $^{x}$} & \multirow[b]{2}{*}{ Species } & \multirow[b]{2}{*}{ Host } & \multirow[b]{2}{*}{ Origin } & \multicolumn{2}{|c|}{ GenBank accession $^{w}$} \\
\hline & & & & ITS & $\beta$ - tubulin \\
\hline \multicolumn{6}{|c|}{ Isolated from avocado fruit with stem-end rot $^{\mathrm{y}}$} \\
\hline UCR1359 & Neofusicoccum luteum & Persea americana & California & JX869032 & JX898979 \\
\hline UCR1211 & N. luteum & P. americana & California & JX869033 & JX898980 \\
\hline UCR1214 & N. luteum & P. americana & California & JX869034 & JX898981 \\
\hline UCR1273 & N. luteum & P. americana & California & JX869035 & JX898982 \\
\hline UCR1275 & N. luteum & P. americana & California & JX869036 & JX898983 \\
\hline UCR1336 & N. luteum & P. americana & California & JX869037 & JX898984 \\
\hline UCR1340 & N. luteum & P. americana & California & JX869038 & JX898985 \\
\hline UCR1347 & N. luteum & P. americana & California & JX869039 & JX898986 \\
\hline UCR1368 & N. luteum & P. americana & California & JX869040 & JX898987 \\
\hline \multicolumn{6}{|c|}{ Isolated from avocado branch cankers ${ }^{\mathrm{z}}$} \\
\hline UCR509 & Neofusicoccum australe & P. americana & California & GQ857659 & GQ857665 \\
\hline UCR739 & N. australe & P. americana & California & GQ857662 & GQ857668 \\
\hline UCR444 & N. luteum & P. americana & California & HQ529764 & HQ529773 \\
\hline UCR211 & N. luteum & P. americana & California & GQ857658 & GQ857664 \\
\hline UCR455 & N. luteum & P. americana & California & HQ529756 & HQ529726 \\
\hline UCR526 & N. luteum & P. americana & California & HQ529763 & HQ529733 \\
\hline UCR295 & Neofusicoccum parvum & P. americana & California & HQ529765 & HQ529734 \\
\hline UCR531 & N. parvum & P. americana & California & GQ857661 & GQ857667 \\
\hline UCR735 & N. parvum & P. americana & California & HQ529766 & HQ529735 \\
\hline UCR736 & N. parvum & P. americana & California & HQ529767 & HQ529736 \\
\hline UCR737 & N. parvum & P. americana & California & GQ857660 & GQ857666 \\
\hline \multicolumn{6}{|c|}{ Obtained from GenBank } \\
\hline UCD1314 So & N. australe & Vitis vinifera & California & DQ008323 & DQ008346 \\
\hline UCD1467 So & N. australe & $V$. vinifera & California & DQ233610 & DQ233631 \\
\hline CMW6837 & N. australe & Acacia sp. & Australia & AY339262 & AY339254 \\
\hline UCD2089Te & N. luteum & $V$. vinifera & California & DQ233605 & DQ233626 \\
\hline CMW9076 & N. luteum & Malus $\times$ domestica & New Zealand & AY236946 & AY236922 \\
\hline CMW10310 & N. luteum & $V$. vinifera & Portugal & AY339259 & AY339251 \\
\hline
\end{tabular}


most-parsimonious tree, a partition homogeneity test with 1,000 random repartitions was performed in PAUP* (version 4.0b10; Sinauer Associates, Sunderland, MA) to determine whether ITS and $\beta$-tubulin sequence data could be combined. Tree length, consistency index (CI), retention index (RI), rescaled consistency index (RC), and homoplasy index (HI) were calculated using MEGA 5.0.

Analysis of molecular variance (AMOVA) was performed using GenAIEx6 (19) to estimate the variance components between and within two groups of isolates of $N$. luteum recovered from stemend rot or branch cankers.

Pathogenicity tests. Six isolates were used in the pathogenicity tests: three isolates from stem-end rot (UCR1301, C. gloeosporioides; UCR1359, N. luteum; and UCR1395, Phomopsis sp.) and three Botryosphaeriaceae isolates from branch cankers (16) (UCR295, N. parvum; UCR444, N. luteum; and UCR509, N. australe).

Mature Hass fruit freshly harvested by clipping at the Agricultural Operations field station of the University of California, Riverside, were surface disinfected by dipping into a $1.5 \% \mathrm{NaOCl}$ solution for $1 \mathrm{~min}$, rinsed with water, and allowed to air-dry. For each isolate, two methods were used for inoculation: (i) mycelial agar discs (5 mm diameter) from the edge of actively growing cultures were placed into a hole on the pedicel (stem) that was made with a 5-mm-diameter cork borer and covered with Parafilm; and (ii) the pedicel was removed from fruits by snapping, and $50 \mu \mathrm{l}$ of a conidial suspension $\left(1 \times 10^{5}\right.$ conidia/ml $)$ was placed onto the stem-end opening. For both methods, fruit were placed in plastic crispers and incubated at approximately $25^{\circ} \mathrm{C}$ and $>80 \%$ relative humidity. Inoculated fruit and controls (mock inoculated with agar plugs or sterile distilled water) were arranged in a randomized complete block design with six replications. After 12 days, fruit were cut open lengthwise for evaluation. Stem-end rot was rated using a scale from 0 to 4 , where $0=$ no visible rot; $1=1$ to $25 \% ; 2=25$ to $50 \% ; 3=50$ to $75 \%$; and $4=>75 \%$ of fruit surface decayed. Pathogenicity tests using both inoculation methods were conducted twice. Small pieces of the flesh removed from the margin of the rot were placed on PDA-tet. Fungal colonies were compared morphologically to those of isolates used in the inoculations.

Data analysis. Percent stem-end rot data from repeated experiments were tested for homogeneity of error variance by analysis of variance (ANOVA) in PROC GLM of SAS (version 9.2; SAS Institute Inc., Cary, NC). As no heterogeneity was detected, pooled data were tested by ANOVA in PROC GLM of SAS. Means were compared using Tukey's honest significant difference (HSD) mean separation test at $\alpha=0.05$. Pearson's correlation (PROC CORR)

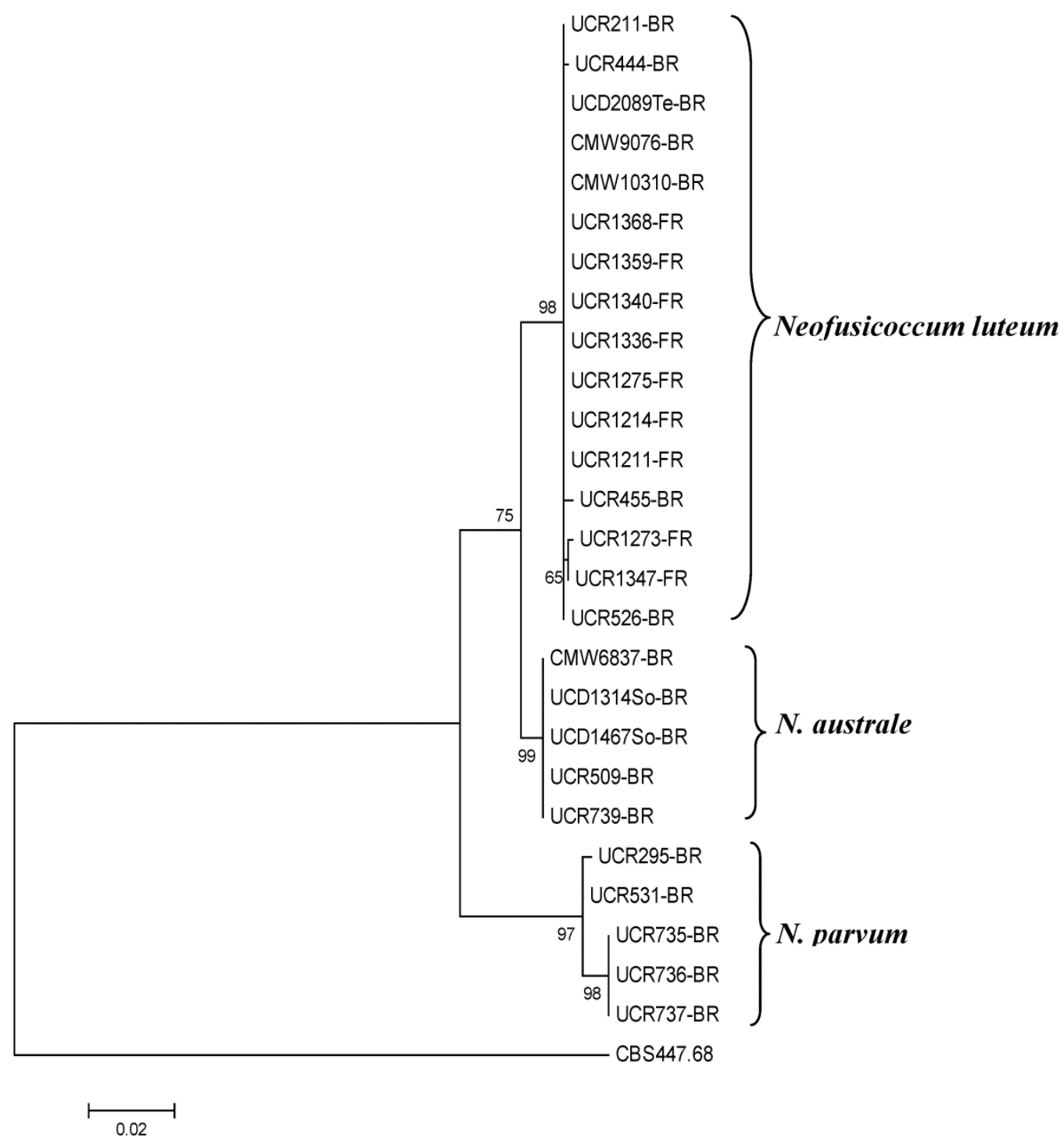

Fig. 1. Most parsimonious unrooted tree based on internal transcribed spacer (ITS)1,5.8S rDNA, ITS2, and partial $\beta$-tubulin gene sequences of isolates belonging to the genus Neofusicoccum inferred from maximum parsimony analysis using MEGA 5.0. Numbers on branches are bootstrap values $>50 \%$ in 1,000 replicates. Isolate CBS447.68 (Guignardia philoprina) deposited to the GeneBank by CBS (Centraalbureau voor Schimmelcultures, Utrecht, The Netherlands), was added as an outgroup. FR = isolates recovered from fruit stem-end rot; $B R=$ isolates recovered from branch cankers. 
was used to establish the relationship between stem-end rot severity after inoculation with mycelial plugs and severity using conidial suspensions. A paired sample $t$ test was conducted to examine whether there was a difference between means of the two inoculation methods.

\section{Results}

Fungal identification. A total of 177 fungal isolates were recovered from avocado fruit with stem-end rot. Morphological comparisons with reference isolates identified 114, 59, and 4 of these isolates as N. luteum, C. gloeosporioides, and Phomopsis sp., respectively. $N$. luteum isolates had buff-colored, aerial hyphae in patchy tufts that covered the surface of the medium in an $85-\mathrm{mm}$ petri plate in 2 to 3 days. Conidia measuring $20.7 \pm 1.7 \mu \mathrm{m}$ (length) and $7.3 \pm 0.5 \mu \mathrm{m}$ (width) were hyaline, aseptate, and fusiform. Cultures were characterized by very pale yellow to bright yellow pigments in the center on the reverse of the plate. Colonies of $C$. gloeosporioides isolates were dense aerial, initially white to gray, becoming dark gray as the cultures aged. Conidia $(8.1 \pm 2.1 \times$ $5.3 \pm 2.1 \mu \mathrm{m})$ were hyaline, aseptate, and cylindrical with obtuse apices. Phomopsis sp. isolates had whitish or pale to pale grayish colonies.

ITS and $\beta$-tubulin sequences were obtained from 57 isolates, and representative sequences were deposited in GenBank with accession numbers indicated in Table 1. Sequence comparisons in GenBank assigned 37 isolates to N. luteum, 18 isolates to C. gloeosporioides, and 2 isolates to Phomopsis sp., and these assignments matched the morphological identifications.

Phylogenetic analysis and genetic variation. The nonsignificant partition-homogeneity test $(P=1.00)$ indicated congruence between ITS and $\beta$-tubulin sequence sets, and thus, both sets were combined for further phylogenetic analysis. Of the 1,154 nucleotides analyzed, 54 were informative. Maximum parsimony analysis yielded a total of 740 trees (length $=232, \mathrm{CI}=0.98, \mathrm{RI}=0.98, \mathrm{RC}$ $=0.96$, and $\mathrm{HI}=0.04)$ with three well-defined clusters with little sequence variability among isolates within each cluster (Fig. 1). The first cluster consisted of nine isolates of $N$. luteum from fruit stem-end rot and seven isolates of $N$. luteum from branch cankers. The second and third clusters consisted of five isolates each of $N$. australe and $N$. parvum, respectively, obtained from branch cankers. Results from AMOVA revealed a significant $(P<0.01)$ genetic differentiation within and between two groups of isolates of $N$. luteum recovered from stem-end rot or branch cankers. The variance between groups was $20 \%$, and that within groups was $80 \%$ (Table 2).
Pathogenicity tests. Although severity of stem-end rot using both inoculation methods was significantly different $(P=0.018$ for two-tailed $t$ test), Pearson's correlation indicated a strong positive relationship between both methods $(r=0.91, n=96, P<0.0001)$. Isolates of three fungal species recovered from fruit stem-end rot differed significantly $(P<0.05)$ in causing stem-end rot of Hass avocado fruit (Table 3). Fruit inoculated with $N$. luteum caused the highest stem-end rot severity with 84.4 and $78.3 \%$ of the cut-open fruit surface decayed using mycelial plugs and conidial suspensions, respectively. Isolates of Phomopsis sp. and C. gloeosporioides were less virulent and resulted in a similar $(P>0.05)$ low stem-end rot severity using both inoculation methods. A high severity of stem-end rot also developed from inoculations with fungal species from branch cankers. An isolate of $N$. luteum from branch cankers was similarly virulent (severity 74.5 to $83.0 \%$ ) as the isolate of the same species obtained from stem-end rot (Table $3)$. Furthermore, inoculations with isolates of $N$. parvum and $N$. australe originating from branch cankers also resulted in a similar $(P>0.05)$ high severity of stem-end rot, although decay development after inoculation with mycelial plugs of $N$. australe was lower. In reisolations, fungi used in the inoculations were successfully recovered ( 80 to $100 \%$ ) when small pieces of decayed tissue were placed onto agar medium.

\section{Discussion}

Avocado stem-end rot in a major avocado growing region of California was found to be caused by N. luteum, C. gloeosporioides, and a Phomopsis species. The most frequently isolated species in our 2-year survey was $N$. luteum. This species was previously reported to be a major avocado stem-end rot pathogen in Australia, New Zealand, and South Africa $(4,12,18)$. Similar to studies conducted in New Zealand (9), species of Phomopsis were found to be of minor importance in causing stem-end rot in our study. $B$. dothidea, previously reported as the primary species causing stem-end rot in the United States (17), was not recovered from avocado fruit with stem-end rot in our study; however, it may occur in avocado growing areas that were not sampled. Alternatively, with the more recent use of molecular methods in fungal identification and changes in the taxonomy of the Botryosphaeriaceae (2), the causal agent of stem-end rot may have been misidentified in earlier studies. Based on DNA sequence data, most of the isolates first identified as $B$. dothidea were reassigned to different species, primarily within the genus Neofusicoccum (23).

In previous research conducted in Southern California, $82 \%$ of the fungi associated with avocado branch cankers belonged to the

Table 2. Analysis of molecular variance between and within two groups of isolates of Neofusicoccum luteum recovered from either stem-end rot or branch cankers

\begin{tabular}{lccccc}
\hline Source of variation $^{\mathbf{z}}$ & df & Sum of squares & Mean squares & Variance component & \% Variation \\
\hline Between groups & 1 & 2.863 & 2.863 & 0.239 & 20 \\
Within groups & 14 & 13.762 & 0.983 & 0.983 \\
Total & 15 & 16.625 & $\ldots$ & 1.222 & 80 \\
\hline
\end{tabular}

${ }^{\mathrm{z}}$ Hierarchical analysis based on groups of nine and seven isolates from avocado stem-end rot and branch cankers, respectively.

Table 3. Stem-end rot severity of 'Hass' avocado fruit inoculated with fungi isolated from stem-end rot or branch cankers on avocado

\begin{tabular}{|c|c|c|c|c|}
\hline \multirow[b]{2}{*}{ Isolate } & \multirow[b]{2}{*}{ Species } & \multirow[b]{2}{*}{ Source } & \multicolumn{2}{|c|}{ Stem-end rot $(\%)^{\mathrm{y}}$} \\
\hline & & & Mycelial plugs & Conidial suspension \\
\hline UCR1359 & Neofusicoccum luteum & Fruit & $84.4 \mathrm{a}$ & $78.3 \mathrm{a}$ \\
\hline UCR1301 & Colletotrichum gloeosporioides & Fruit & $33.3 \mathrm{c}$ & $27.8 \mathrm{~b}$ \\
\hline UCR1395 & Phomopsis sp. & Fruit & $18.8 \mathrm{c}$ & $25.3 \mathrm{~b}$ \\
\hline UCR444 & N. luteum & Branch canker & $83.0 \mathrm{a}$ & $74.5 \mathrm{a}$ \\
\hline UCR295 & Neofusicoccum parvum & Branch canker & $77.3 \mathrm{ab}$ & $70.8 \mathrm{a}$ \\
\hline UCR509 & Neofusicoccum australe & Branch canker & $65.6 \mathrm{~b}$ & $67.5 \mathrm{a}$ \\
\hline Control $^{\mathrm{z}}$ & & & $1.1 \mathrm{~d}$ & $1.3 \mathrm{c}$ \\
\hline
\end{tabular}

${ }^{\text {y }}$ Fruit were inoculated with mycelial plugs or a conidial suspension of each isolate. Data are mean values of stem-end rot severity that was based on percentage of the longitudinally cut open decayed fruit. Means followed by the same letter within columns are not significantly different $(P<0.05)$ according to Tukey's honest significant difference (HSD) mean separation test.

${ }^{\mathrm{z}}$ Fruit were inoculated with agar plugs without fungal mycelium or with sterile distilled water. 
Botryosphaeriaceae, with $N$. luteum and $N$. australe being the predominant species (16). Similarly to the current stem-end rot survey, Phomopsis sp. was associated with a lower incidence in the avocado branch canker study (16). N. australe, however, was not recovered from stem-end rot, although we demonstrated it to be pathogenic and highly virulent in stem-end inoculations of avocado fruit. Additionally, in our comparative pathogenicity studies, stemend rot and branch canker isolates of $N$. luteum caused a similar severity of stem-end rot. An isolate of $N$. parvum from a branch canker was also as virulent as $N$. luteum on avocado fruit. These results indicate that branch cankers can be a source of inoculum for fruit infections and that species not detected in our stem-end rot survey in California can potentially cause stem-end decay. Conversely, it is possible that species from stem-end rot lesions could cause branch cankers. $N$. parvum is known as an avocado stem-end rot pathogen in Australia, New Zealand, and South Africa $(13,17)$, but $N$. australe has never been reported to cause avocado stem-end rot.

Hierarchical analysis of genetic variation indicated that isolates of $N$. luteum from branch cankers could not be genetically separated from those obtained from stem-end rot. There was low genetic diversity within this species, and $20 \%$ of the diversity was distributed between the two groups of isolates (isolates from stemend rot or branch cankers), while $80 \%$ was distributed within groups. This indicates that both groups are closely related.

C. gloeosporioides was a weaker stem-end rot pathogen in our inoculation studies compared to the three members of the Botryosphaeriaceae. This species, however, also causes anthracnose of avocado fruit that can result in serious postharvest crop losses. Previous studies by others also identified $C$. gloeosporioides as a weak avocado stem-end rot pathogen (26). It was reported as an important pathogen, however, when present in combination with other stem-end rot fungi, such as in the Dothiorella/Colletotrichum rot complex (3).

Results of this research emphasize the potential impact of branch canker and dieback diseases on the occurrence of fruit stem-end rot of avocado and the importance of integrated management of orchard diseases. Preharvest and postharvest fungicide applications for the control of stem-end rot have been used with some success in other parts of the world $(5,14)$, but not in the United States. Thus, a critical aspect for minimizing stem-end rot is orchard sanitation and optimal cultural practices such as pruning and harvesting only during dry conditions, disposing of dead wood and old fruit away from avocado trees, providing sufficient irrigation, and correcting nutritional stresses (26). Fruit should be picked by clipping instead of snapping the pedicels, and clippers should be frequently sterilized (13). Harvested fruit should be stored at optimal temperatures, and proper sanitation practices should be followed in the packinghouse.

To further elucidate the etiology of avocado stem-end rot in California, follow-up studies should be done in additional locations and during years of high rainfall. Clearly, species other than the ones described in this study may be involved in causing the disease in California. Furthermore, based on the occurrence of the disease under different climatic conditions, additional preharvest and postharvest management practices may need to be developed.

\section{Acknowledgments}

We thank the California Avocado Commission and its members for funding and supporting this research.

\section{Literature Cited}

1. Cenis, J. L. 1992. Rapid extraction of fungal DNA for PCR amplification. Nucleic Acids Res. 20:2380.
2. Crous, P. W., Slippers, B., Wingfield, M. J., Rheeder, J., Marasas, W. F. O. Phillips, A. J. L., Alves, A., Burgess, T., Barber, P., and Groenewald, J. Z. 2006. Phylogenetic lineages in the Botryosphaeriaceae. Stud. Mycol. 55:235-253.

3. Darvas, J. M. 1978. Stem-end rot and other postharvest diseases. South Afr. Avocado Growers' Assn. Yearb. 2:49-51.

4. Darvas, J. M., Kotzé, J. M., and Wehner, F. C. 1987. Pathogenicity of fungi causing pre- and postharvest diseases of avocado fruit. Phytophylactica 19:489-493.

5. Darvas, J. M., Kotzé, J. M., and Wehner, F. C. 1990. Effect of treatment after picking on the incidence of postharvest diseases of avocado. Phytophylactica 22:93-96.

6. Dreistadt, S. H. 2008. Integrated Pest Management for Avocados. University of California, Agriculture and Natural Resources. Publ. No. 3503 Oakland, CA.

7. Eskalen, A., Faber, B., and Bianchi, M. 2013. Spore trapping and pathogenicity of fungi in the Botryosphaeriaceae and Diaporthaceae associated with avocado branch canker in California. Plant Dis. 97:329-332.

8. Everett, K. R. 1999. Orchard survey: Effect of pre-harvest factors on postharvest rots. HortResearch Client Report No. 1999/266.

9. Everett, K. R., Rees-George, J., Parkes, S. L., and Johnston, P. R. 2003. Predicting avocado fruit rots by quantifying inoculum potential in the orchard before harvest. Pages 601-606 in: Proc. 5th World Avocado Congr. Viceconsejeria. Servicio de Publicaciones y Divulgacion.

10. Faber, B., Eskalen, A., and Bender, G. 2008. UC IPM Pest Management Guidelines: Avocado, UC ANR Publ. 3436. Oakland, CA.

11. Glass, N., and Donaldson, G. 1995. Development of primer sets designed for use with the PCR to amplify conserved genes from filamentous ascomycetes. Appl. Environ. Microbiol. 61:1323-1330.

12. Hartill, W. F. T. 1991. Post-harvest diseases of avocado fruit in New Zealand. N.Z. J. Crop Hortic. Sci. 19:297-304.

13. Hartill, W. F. T., and Everett, K. R. 2002. Inoculum sources and infection pathways of pathogens causing stem-end rots of 'Hass' avocados. N.Z. J. Crop Hortic. Sci. 30:249-260.

14. Hartill, W. F. T., Fowler, M., Sale, P. R., and Sawden, D. S. 1990. The effect of copper sprays and dead wood removal on the incidence of postharvest rots. Sci. Res. Tech. Suppl. No. 7:4-6.

15. Johnson, G. L., and Kotzé, J. M. 1994. Stem-end rot. Pages 81-83 in: Compendium of Tropical Fruit Diseases. R. C. Ploetz, G. A. Zentmyer, W. T. Nishijima, K. G. Rohrbach, and H. D. Ohr, eds. American Phytopathological Society, St Paul, MN.

16. McDonald, V., and Eskalen, A. 2011. Botryosphaeriaceae species associated with avocado branch cankers in California. Plant Dis. 95:1465-1473.

17. Menge, J. A., and Ploetz, R. C. 2003. Diseases of avocado. Pages 35-71 in: Diseases of Tropical Fruit Crops. R. C. Ploetz, ed. CABI Publishing, Wallingford, UK.

18. Muirhead, I. F., Fitzell, R. D., Davis, R. D., and Peterson, R. A. 1982. Postharvest control of anthracnose and stem-end rots of Fuerte avocado with prochloraz and other fungicides. Aust. J. Exp. Agric. Anim. Husb. 22:441446.

19. Peakall, R., and Smouse, P. E. 2006. GenAIEx 6: Genetic analysis in Excel. Population genetic software for teaching and research. Mol. Ecol. Notes 6:288-295.

20. Peterson, R. A., and Inch, A. J. 1980. Control of anthracnose on avocados in Queensland. Qld. J. Agric. Anim. Sci. 37:79-83.

21. Prusky, D., Keen, N. T., and Eaks, I. 1983. Further evidence for the involvement of a preformed antifungal compound in the latency of Colletotrichum gloeosporioides on unripe avocado fruits. Physiol. Plant Pathol. 22:189-198.

22. Rowell, A. W. G. 1983. Post-harvest disease control in avocados using prochloraz. South Afr. Avocado Growers' Assn. Yearb. 6:19.

23. Slippers, B., Crous, P. W., Denman, S., Coutinho, T. A., Wingfield, B. D. and Wingfield, M. J. 2004. Combined multiple gene genealogies and phenotypic characters differentiate several species previously identified as Botryosphaeria dothidea. Mycologia 96:83-101.

24. Timmer, L. W., Garnsey, S. M., and Graham, J. H. 2000. Compendium of Citrus Diseases. American Phytopathological Society, St. Paul, MN.

25. White, T. J., Bruns, T., Lee, S., and Taylor, J. 1990. Amplification and direct sequencing of fungal ribosomal RNA genes for phylogenetics. Pages 315322 in: PCR Protocols: A Guide to Methods and Applications. M. A. Innis, D. J. Gelfand, J. J. Sninsky, and T. J. White, eds. Academic Press, New York.

26. Yahia, E. M. 2012. Avocado. Pages 159-179 in: Crop Post-Harvest: Science and Technology, Perishables. D. Rees, G. Farrell and J. Orchard, eds. Wiley-Blackwell, Oxford, UK. 